\title{
Post-Paleozoic evolution of the northern Ardenne Massif constrained by apatite fission-track thermochronology and geological data
}

\author{
Jocelyn Barbarand ${ }^{1, *}$, Ivan Bour ${ }^{1}$, Maurice Pagel ${ }^{1}$, Florence Quesnel $^{2,3}$, Bernard Delcambre ${ }^{4}$, \\ Christian Dupuis ${ }^{5}$ and Johan Yans ${ }^{6}$ \\ ${ }^{1}$ GEOPS, Université Paris-Sud, CNRS, Université Paris-Saclay, Rue du Belvédère, Bât. 504, 91405 Orsay, France \\ 2 BRGM (French Geological Survey), DGR/GAT, BP 36009, 45060 Orléans cedex 2, France \\ ${ }^{3}$ UMR 7327 BRGM-Université d'Orléans-CNRS, Campus Géosciences, 1A rue de la Férollerie, 45071 Orléans cedex 2, France \\ ${ }^{4}$ Université Catholique de Louvain, Earth and Life Institute, pl. L. Pasteur, 3-B-1348 Louvain-la-Neuve, Belgium \\ ${ }^{5}$ Géologie Fondamentale et Appliquée, Faculté Polytechnique de Mons, Université de Mons, 9 rue de Houdain, 7000 Mons, Belgium \\ ${ }^{6}$ University of Namur, Department of Geology, "Institute of Life, Earth and Environment" ILEE, 61 rue de Bruxelles, 5000 Namur, \\ Belgium
}

Received: 27 March 2018 / Accepted: 6 September 2018

\begin{abstract}
The exhumation history of basement areas is poorly constrained because of large gaps in the sedimentary record. Indirect methods including low temperature thermochronology may be used to estimate exhumation but these require an inverse modeling procedure to interpret the data. Solutions from such modeling are not always satisfactory as they may be too broad or may conflict with independent geological data. This study shows that the input of geological constraints is necessary to obtain a valuable and refined exhumation history and to identify the presence of a former sedimentary cover presently completely eroded. Apatite fission-track (AFT) data have been acquired on the northern part of the Ardenne Massif close to the Variscan front and in the southern Brabant, in particular for the Visean ash-beds. Apatite fission-track ages for surface samples range between $140 \pm 13$ and $261 \pm 33 \mathrm{Ma}$ and confined tracks lengths are ranging between $12.6 \pm 0.2$ and $13.8 \pm 0.2 \mu \mathrm{m}$. Thermal inversion has been realized assuming that (1) samples were close to the surface $\left(20-40^{\circ} \mathrm{C}\right)$ during Triassic times, this is supported by remnants of detrital Upper Permian-Triassic sediments preserved in the south of the Ardenne and in the east (border of the Roer Graben and Malmédy Graben), and (2) terrestrial conditions prevailed during the Early Cretaceous for the Ardenne Massif, as indicated by radiometric ages on paleoweathering products. Inversion of the AFT data characterizes higher temperatures than surface temperatures during most of the Jurassic. Temperature range is wide but is compatible with the deposition on the northern Ardenne of a significant sedimentary cover, which has been later eroded during the Late Jurassic and/or the Early Cretaceous. Despite the presence of small outliers of Late Cretaceous (Hautes Fagnes area), no evidence is recorded by the fission-track data for the deposition of a significant chalk cover as highlighted in different parts of western Europe. These results question the existence of the London-Brabant Massif as a permanent positive structure during the Mesozoic.
\end{abstract}

Keywords: Ardenne Massif / apatite fission-track thermochronology / erosion / Paris Basin / Western Europe geodynamics

\begin{abstract}
Résumé - Histoire post-Paléozoïque du nord du massif de l'Ardenne reconstituée à partir de la thermochronologie traces de fission dans les cristaux d'apatite et des données géologiques. L'évaluation des épaisseurs érodées sur les socles n'est pas immédiate car l'absence fréquente de couverture sédimentaire rend muette leur quantification sur une grande période de temps. Des méthodes indirectes comme la thermochronologie basse température permettent d'appréhender l'érosion à condition d'inverser correctement les données par modélisation. Les résultats de l'inversion ne sont pas toujours en accord avec les données géologiques ou sont trop imprécis pour être pertinents. Cette étude montre que la prise en compte de contraintes géologiques est nécessaire pour obtenir une histoire cohérente, définir l'ampleur de
\end{abstract}

\footnotetext{
*Corresponding author: jocelyn. barbarand@u-psud.fr
} 
l'érosion et identifier la présence d'une couverture sédimentaire aujourd'hui érodée. Des données traces de fission dans les cristaux d'apatite ont été réalisées dans le nord du massif de l'Ardenne à proximité du front varisque et au sud du Massif du Brabant, en particulier sur des échantillons de cinérites viséennes. Les âges traces de fission des échantillons prélevés à la surface varient entre $140 \pm 13$ et $261 \pm 33$ Ma et la longueur

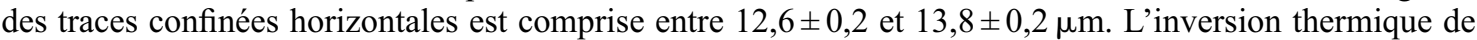
ces données a été réalisée en prenant comme hypothèses : (1) la proximité des échantillons de la surface (20 $40^{\circ} \mathrm{C}$ ) au cours du Trias, hypothèse étayée par des témoins de couverture du Permien supérieur et du Trias au sud et à l'est du massif de l'Ardenne (grabens de la Roer et de Malmédy); (2) l'existence de conditions continentales au cours du Crétacé inférieur, en accord avec des âges de cette période pour des profils d'altération datés localisés dans le massif de l'Ardenne. Le résultat de cette inversion suggère des températures assez élevées au cours du Jurassique. Ces températures sont interprétées comme le résultat du dépôt d'une couverture sédimentaire qui a ensuite été érodée au Jurassique supérieur et/ou au Crétacé inférieur. Malgré la présence de quelques témoins du Crétacé supérieur (notamment dans les Hautes Fagnes), les données ne permettent pas de détecter le dépôt d'une série épaisse datée du Crétacé supérieur comme c'est le cas dans plusieurs régions d'Europe de l'Ouest. Ces résultats remettent en question l'existence de la structure positive du massif de Londres-Brabant au cours du Jurassique en identifiant des mouvements verticaux significatifs.

Mots clés : massif de l'Ardenne / traces de fission dans les cristaux d'apatite / érosion / bassin de Paris / géodynamique de l'Europe de l'Ouest

\section{Introduction}

The post-chain evolution of intracontinental basement areas is difficult to reconstruct because these domains are often devoid of younger sedimentary rocks. These basement areas have long been considered stable as they are remote from places of intense tectonic activity. However, recent studies have pointed up the occurrence of intraplate lithospheric deformation associated with plate boundary dynamics (review in Cloetingh and Burov, 2011) or mantle dynamics (Braun, 2010). The former sedimentary cover of these domains and their relationship with the neighboring basins are poorly constrained although they closely control paleogeography and lithospheric dynamics. These features are particularly difficult to ascertain as sedimentary infilling and exhumation are of low amplitude and cannot be detected by most standard methods of reconstructing erosion. Apatite fission-track (AFT) thermochronology has been successfully applied to the Mesosoic and Cenozoic evolution of the Caledonian and Variscan basements of Europe (Green, 1986; Larson et al., 1995; Wagner et al., 1997; Barbarand et al., 2001, 2013) and these studies have revealed that significant thicknesses of Mesozoic sediments (mainly Cretaceous in age) were deposited and then eroded in these areas. Although this method is appropriate due to its lowtemperature sensitivity domain $\left(60-110^{\circ} \mathrm{C}\right.$, Green et al., 1989), data have to be interpreted using an inversion model for thermal histories to match with the data. While such modeling is easy in domains where vertical movements are large, lowamplitude deformation requires the introduction of robust geological constraints to decipher plausible thermal evolution.

A fission-track study on apatite crystals has been undertaken in the northern Ardenne and Brabant Massifs to test the effect of robust geological constraints on the interpretation of apatite fission-track data. The Ardenne Massif has been located in an intracontinental setting since the end of the Variscan orogeny, although it may have experienced regional deformations (opening of the North
Atlantic Ocean, uplift and opening of the North Sea rift, collision between the European and African plates, opening of the Cenozoic grabens; see Ziegler (1990), Færseth (1996), Rosenbaum et al. (2002), Dèzes et al. (2004)). The postVariscan evolution of the Ardenne Massif is still poorly understood given the potentially large impact of geodynamic events affecting the northwestern European margin. So far the vertical evolution of the Ardenne Massif during the Mesozoic remains an open question. The first AFT study was carried out in the northern part of the Ardenne and Brabant Massifs (Fig. 1) by van den Haute and Vercoutere (1989). Subsequent AFT analyses were conducted on the northern edge of the Ardenne and in the western part of the Dinant Paraautochthonous zone but without thermal inverse modeling (Vercoutere and Van den Haute, 1993). Glasmacher et al. (1998) also made an AFT study of the Stavelot Massif (Fig. 1) in the eastern part of the Ardenne and in the close Rhenish Massif. The Rhenish Massif and the Ruhr Carboniferous Basin have been studied by Karg et al. (2005). The latest fission-track study (Xu et al., 2009) covers a NE-SW axis between the Variscan front and the Givonne Massif. These studies conclude there has been either continuous slow cooling from the Late Carboniferous to the Tertiary (Xu et al., 2009) or episodic faster cooling (Jurassic for Vercoutere and Van den Haute, 1993 or mid-Cretaceous for Glasmacher et al., 1998) with significant erosion of Paleozoic rocks. Analysis of the sedimentary infilling of the adjacent basins (Paris Basin to the SW and West Netherlands Basin to the NE) reveals also the presence of regional unconformities since the Permian and especially during the Middle Jurassic, Early Cretaceous and the Cenozoic (e.g. Ziegler, 1990; Guillocheau et al., 2000). The meaning of these unconformities and their link with potential erosion phases observed in nearby basements need to be addressed.

The objective of this work is to characterize the vertical evolution of the northern Ardenne and the Brabant massifs considering new fission-track data, using robust geological 


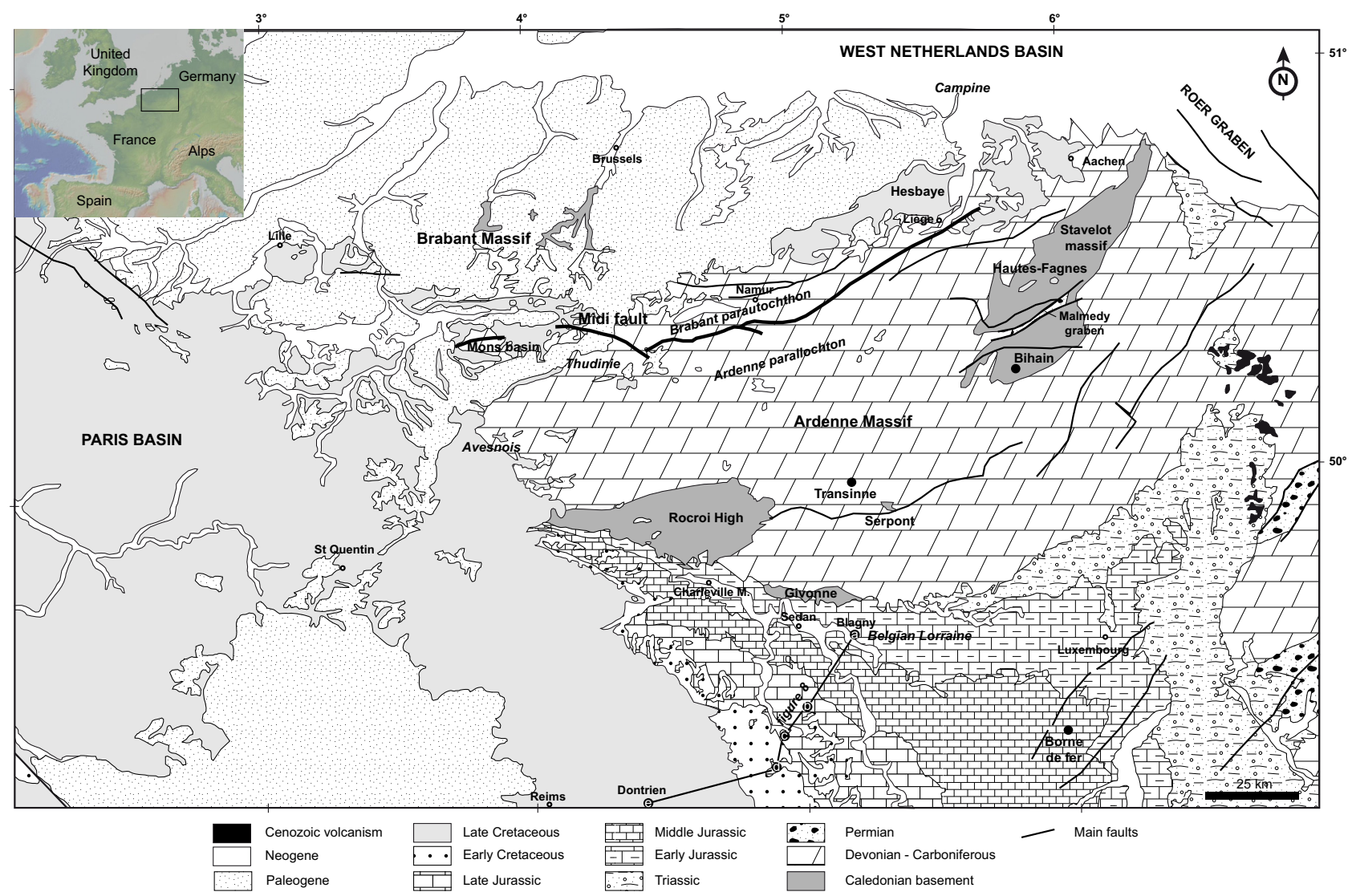

Fig. 1. Geological map of Northern France and Belgium (after De Vos et al., 1992; Chantraine et al., 2003). Boreholes used in Figure 8 are: (a) Blagny; (b) Sommauthe; (c) Briquenay; (d) Grandpré; (e) Dontrien.

constraints, in order to investigate relationships between these domains and the nearby basins.

\section{Geological context}

\subsection{Variscan framework}

The pre-Permian basement of the Ardenne contains Paleozoic sedimentary rocks which experienced the Caledonian (only for Cambrian to Silurian) and Variscan orogenies (e.g. Fielitz and Mansy, 1999). This basement belongs to the main Rhenish Massif, which is well exposed in Germany. These massifs were structured from North to South into three units during the Variscan orogeny (mainly Late Carboniferous): the Brabant Para-autochthon, the tectonic wedges of the Paraautochthonous (also called "the Haine-Sambre-Meuse Overturned Thrust Sheets" or HSM-OTS), and the Ardenne Allochthon (Lacquement et al., 1999; Mansy et al., 2003; Belanger et al., 2012). The Ardenne Allochthon overthrusts the tectonic wedges of the Para-autochthonous through the complex detachment of the "Midi" Fault and its eastern equivalent, the Eifelian Fault.

The Ardenne Allochthon is characterized by a thick sedimentary pelitic-arenitic series of Early Devonian age. Cambrian-Ordovician basement crops out as inliers (Stavelot, Serpont, Givonne and Rocroi massifs). These units are organized as SW-NE-trending anticline and syncline structures
(Fig.1) and underwent anchizonal-early epizonal metamorphism (Fielitz and Mansy, 1999).

The tectonic wedges of the Para-autochthonous are Devonian to Carboniferous units organized into a succession of synclines and anticlines, which have been partly affected by weaker Variscan metamorphism than the Ardenne Allochthon (Larangé, 2002).

The Brabant massif is formed by Cambrian to Silurian siliciclastic sedimentary rocks that experienced greenschist facies metamorphism and were deformed by the Acadian orogeny during the Early Devonian (Mansy et al., 1999). It is part of a larger domain, the London-Brabant Massif. These rocks are largely hidden to the south by the mildly deformed cover of Devonian-Carboniferous sedimentary rocks of the tectonic wedges of the Para-autochthonous, and by the Mesozoic-Cenozoic cover. The Lower Paleozoic basement crops out only in river valleys.

\subsection{Mesozoic-Cenozoic geological history}

Geological history since the Permian is partly recorded by the sedimentary infillings of the two sedimentary basins bordering the Ardenne Massif: the Paris Basin to the southwest and the West Netherlands Basin and the Roer Valley Graben to the northeast (Fig. 1). These basins result from the breakup of Pangea during Permian times. Their sedimentary infilling is composed mainly of calcareous or clayey units characteristic 
of shallow marine environments with the exception of Lower Jurassic marls and the Upper Cretaceous chalk, which were deposited in deeper environments (Ziegler, 1990; Guillocheau et al., 2000; Dusar et al., 2001). Sandstones are also observed during Triassic and Early Cretaceous. In the Paris Basin, the series is up to $3 \mathrm{~km}$ thick and includes the Germanic Triassic trilogy (Bundsandstein sandstones, Muschelkalk limestones and Keuper evaporites), the Jurassic calcareous units, the sandy, clayey and calcareous units of the Early Cretaceous, the chalk of the Late Cretaceous, and the Cenozoic with its changing facies and depositional environments. The main subsidence occurred during the Jurassic for both basins with a secondary peak during the Cenozoic for the West Netherlands Basin (Brunet and Le Pichon, 1982; Duin et al., 2006).

The rocks found today at the surface of the Ardenne and Brabant Massifs do not record the same sedimentary history. The Brabant Para-autochthonous is overlain by a relatively thick Upper Cretaceous cover and locally by Paleogene and Neogene deposits (Legrand, 1968), whereas the Ardenne Massif has only thin isolated relicts of Mesozoic-Cenozoic strata. Nevertheless, the earliest literature (19th-20th century) reports rather numerous occurrences of residual Cretaceous, Paleogene and Neogene remnants often preserved in paleokarst. Triassic and Jurassic series are absent from the Ardenne Massif except for its southern border (Gaume or Belgian "Lorraine") where these rocks form an extension of the Paris Basin described as the "Luxembourg Gulf" (Boulvain et al., 2001; Schintgen and Förster, 2013) and of the Stavelot Massif (Malmédy Graben; Bultynck et al., 2001). In the N-S Eifel Depression, close to the eastern border of the Ardenne, Triassic infill is up to $650 \mathrm{~m}$ thick in its southern part (Mondorf; Schintgen and Förster, 2013) and $400 \mathrm{~m}$ in the northern part (Mechernich area; Knapp, 1980). This subsidence area extended westward at the expense of the emerged Ardenne area over time (Lucius, 1948; Mader, 1985). The unconformity between Paleozoic rocks and Triassic sandstones is tilted southwards in Belgian "Lorraine" and has been described as a pre-Triassic peneplain. In the North of the Ardenne Massif, 450 m-thick Lower Jurassic marls deposited in open marine environments occur as subcrops in the Roer Valley Graben, Campine (Dusar et al., 2001). Demyttenaere and Laga (1988) describe $483 \mathrm{~m}$ of Jurassic marls, trapped in the Roer Valley Graben, overlain by $61 \mathrm{~m}$ of chalk of the Late Maastrichtian Maastricht Formation. These rocks escaped later erosion by being buried in the Roer Valley Graben. Upper Cretaceous facies and thickness differ substantially in Belgium from region to region but characterize a general progressive onlapping from the West Netherlands Basin towards the south (Felder, 1994; Dusar and Lagrou, 2007; Demoulin et al., 2010). Upper Cretaceous deposits are observed on the Ardenne, in the Hautes-Fagnes area (Stavelot Massif), and contain Late Campanian to Maastrichtian glauconitic sands, flints and silicified chalk, related to the decalcification of chalk (Bless and Felder, 1989; Bless et al., 1991; Felder, 1994; Robaszynski, 2006).

Periodically, during Cenozoic times, several transgressions reached the Brabant and some areas of the Ardenne Massif (Demoulin, 1995; Vandenberghe et al., 2004). On the western edge of the Ardenne, in Avesnois, Thanetian glauconiferous flint conglomerates indicate both flint-bearing chalk erosion and marine transgression on the Paleozoic basement (Quesnel,
2006). "Sparnacian" fluvial flint gravels, sands and organic clay are evidence of terrestrial depositional environments, before another marine sequence with siliciclastic units during the Early Ypresian ("Silts et Sablons de 1'Avesnois", "Sables de Trélon", etc., Quesnel, 2006). Bruxellian (Lower Lutetian) calcareous sands and nummulitic limestones covered the "Entre Sambre et Meuse" (ESEM) (Briart, 1888; Gulink, 1963). Fragments of this limestone are sometimes reworked in the Miocene sands concealed in the giant paleo-karsts scattered on the ESEM plateau. Uppermost Eocene marine sands were trapped and preserved by karst development during the Neogene and currently lie at the base of their infilling (Ertus, 1990; Dupuis and Ertus, 1994; Dupuis et al., 2003). The sea overflowed the Ardenne for the last time during the Oligocene (e.g., Demoulin, 1995; Boulvain and Vandenberghe, 2018; Demoulin et al., 2018) covering its eastern part, between the ESEM and the Hautes Fagnes area (Fig. 1) as a result of tilting of the basement towards the Rhine graben area.

The geological history of the area can be also reconstructed from the study and the dating of weathering profiles capping the Ardenne Massif (Fig. 2). The central Ardenne locally displays large thicknesses of weathered rocks (Dupuis, 1992; Dupuis et al., 1996; Yans, 2003a, b; Thiry et al., 2006; Demoulin et al., 2018). The residual kaolin deposits of Transinne have been dated by several techniques ( $\mathrm{K} / \mathrm{Ar}$ on hollandite, ${ }^{40} \mathrm{Ar} /{ }^{39} \mathrm{Ar}$ on cryptomelane, paleomagnetism) and three main episodes of weathering can be recognized (Yans, 2003a, b; Thiry et al., 2006): (1) Early Cretaceous $(\sim 130 \mathrm{Ma})$ with paleomagnetic and $\mathrm{K} / \mathrm{Ar}$ ages on hollandite ranging from $126 \pm 10$ to $135 \pm 10 \mathrm{Ma}$; (2) early LateCretaceous with $\mathrm{K} / \mathrm{Ar}$ ages on hollandite ranging from $89 \pm 3$ to $95 \pm 6 \mathrm{Ma}$; and (3) Early Miocene with ${ }^{40} \mathrm{Ar} /{ }^{39} \mathrm{Ar}$ ages on cryptomelane of $21 \pm 0.4 \mathrm{Ma}$. Recent $\mathrm{Ar} / \mathrm{Ar}$ dating on cryptomelane has also been performed for the Bihain quarry (Stavelot Massif) confirming an Early Miocene age $(20 \pm 0.2 \mathrm{Ma}-22 \pm 0.6 \mathrm{Ma}$; Demoulin et al., 2018). Potential other phases of weathering are locally recognized in Belgium by Demoulin et al. (2018): 1) at the Late Permian-Early Triassic interval in the Malmedy area, in the Belgian "Lorraine" and in the Ardenne, but these phases remain debatable (see discussion below), and 2) at the PaleoceneEocene transition in the ESEM area and in the northern part of the Mons Basin (Barbier, 2012).

\subsection{Sampling and analytical method}

Samples have been collected during several field surveys to cover the northern Ardenne and the Brabant massifs. The Caledonian basement, Devonian and Carboniferous ash-beds and various Paleozoic and Mesozoic sandy facies were sampled to recover apatite crystals. Of these samples, 19 yield apatite crystals in suitable amounts for apatite fission-track dating (Tab. 1). All the rocks analyzed were outcrop samples except BEL41 which was taken from a drillcore in the Brabant Massif.

AFT analysis was carried out in the GEOPS laboratory (Université Paris-Sud). Apatite concentrates were isolated using the conventional techniques of grinding, density and magnetic separation. Spontaneous tracks were revealed by a solution of nitric acid $\left(\mathrm{HNO}_{3} 5 \mathrm{M}\right)$ during $20 \pm 1$ seconds for 


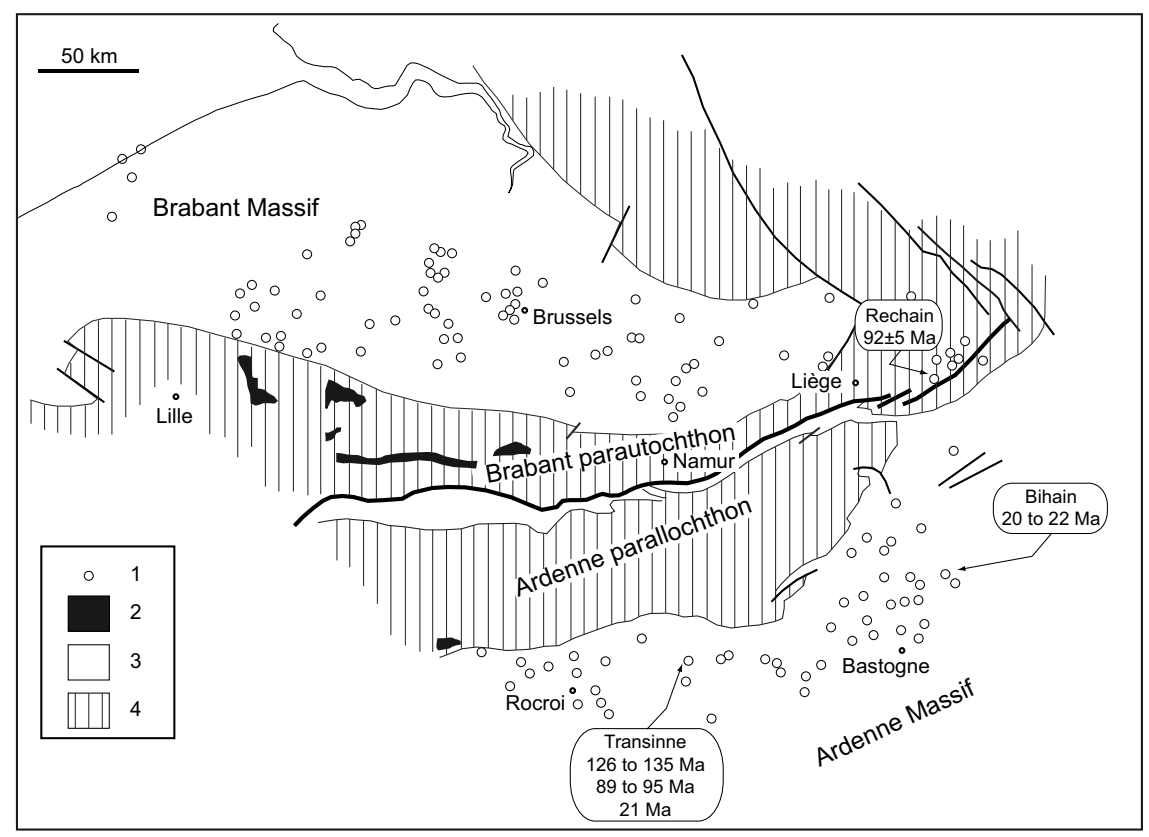

Fig. 2. Kaolinitic paleoweathering map on the Ardenne and Brabant Massifs. 1. Kaolinitic rocks observed in outcrops or boreholes. 2. Wealden facies observed in outcrops or boreholes. 3. Pelito-arenitic type basement (Cambrian to Carboniferous for the Ardenne and Cambrian to Silurian for Brabant). 4. Limestone-type basement (Middle Devonian to Carboniferous). Radiometric ages are presented for the sites which have been dated (see references in the text). Adapted from Dupuis (2002).

a temperature of $20 \pm 1{ }^{\circ} \mathrm{C}$. The external detector technique was used in this study (Gleadow, 1981). Samples were covered by muscovite sheets as external detectors and three glass dosimeters $\mathrm{CN}-5$ as well as two apatite standards (Durango and Fish Canyon Tuff; Hurford, 1990) were irradiated by thermal neutrons. Irradiation was made in the channel P1 of the ORPHEE reactor (Pierre Süe laboratory, CEA, Saclay, France) with a requested fluence of $5.10^{15}$ neutrons $/ \mathrm{cm}^{2}$. Induced tracks were etched by a $40 \%$ fluorhydric acid solution at $20^{\circ} \mathrm{C}$ for 20 minutes. Track counting and measurement were made using a Leica optical microscope at a magnification of $\times 1000$. Tracks were measured in accordance with the recommendations of Laslett et al. (1984) using a digitized tablet associated with a computer. AFT ages are central ages at $\pm 1 \sigma$ (Galbraith and Laslett, 1993). AFT ages were calculated by the zeta calibration approach (Hurford and Green, 1983) where the zeta value is determined by multiple analyses of apatite standards (Durango, Fish Canyon Tuff) following the recommendations of Hurford (1990). Eleven standard samples resulting from six different irradiations with their associated dosimeters were measured to determine a zeta value (IB) of $325 \pm 4$. Dpar measurements were used to characterize the kinetic properties of individual apatite crystals (Burtner et al., 1994; Barbarand et al., 2003b). Thermal modeling was realized using the track-annealing model developed by Ketcham et al. (2007) and the AFTSolve software (Ketcham et al., 2000; Ketcham, 2005) using 50000 iterations.

Apatite composition was determined for five samples covering a large range of Dpar values using a Cameca SX100 electron probe with a wavelength dispersive system and a counting time of 30 seconds.

\section{Results}

\subsection{Apatite fission-track data}

Fission-track ages for outcrop samples range from $140 \pm 13$ to $261 \pm 33 \mathrm{Ma}$ (Fig. 3); sample BEL41 recovered in drillhole at a depth of $745 \mathrm{~m}$ is slightly younger $(114 \pm 8 \mathrm{Ma})$. All samples pass the $\chi^{2}$ test with values higher than the $5 \%$ level and thus characterize a single-age population. Relatively large age variation exists and is partly correlated to the sample position: ages increase southwards and younger ages are measured mainly in the Brabant Massif (Fig. 4).

Because of the low $U$ content of apatite crystals (below $20 \mathrm{ppm}$ for most of the grains), the probability of finding confined tracks is low and a sufficient number of tracks has been found for only a few samples. Considering samples with more than 20 confined tracks measured, mean confined track length is homogeneous and ranges from $12.6 \pm 0.2( \pm 1$ standard error of the mean) to $13.7 \pm 0.2 \mu \mathrm{m}$ with a standard deviation of 0.9 to $1.4 \mu \mathrm{m}$ (Figs. 3 and 4 ). With respect to the limited amount of measured confined track length, track length distributions appear unimodal and negatively skewed.

Dpar values are homogeneous within each sample but vary from 1 to $2.2 \mu \mathrm{m}$ between samples. This wide distribution reproduces the large variety of samples analyzed: apatites from crystalline rocks show Dpar in the 1-1.2 $\mu \mathrm{m}$ range and are Fapatites whereas apatite crystals from ash-levels have higher $\mathrm{Cl}$ content and higher Dpar (1.3 to $2.2 \mu \mathrm{m}$ ).

\subsection{Thermal history modeling}

The thermal history was modeled for all the samples where a minimum of 20 tracks has been measured. This relatively low 


\section{要}

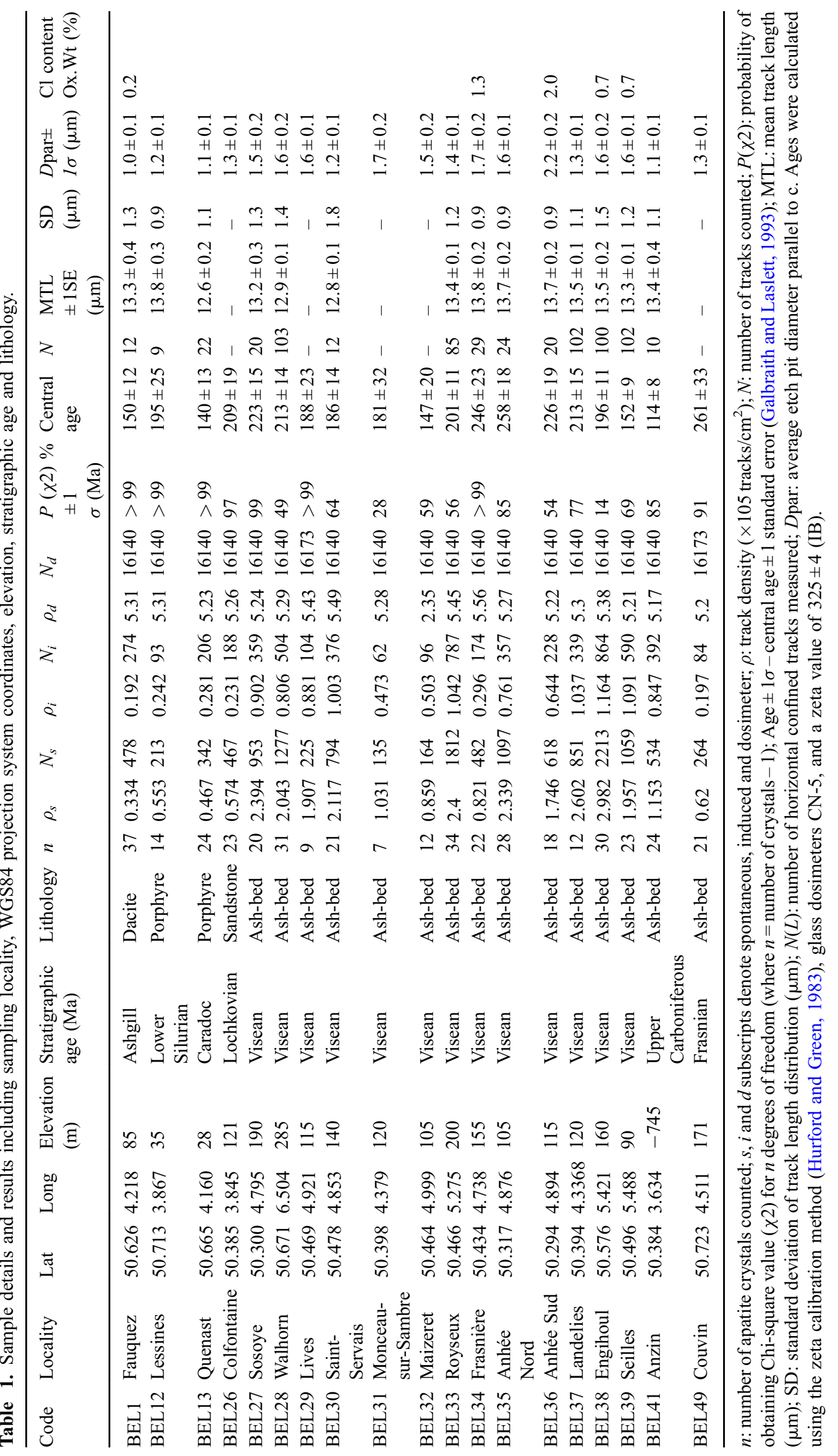




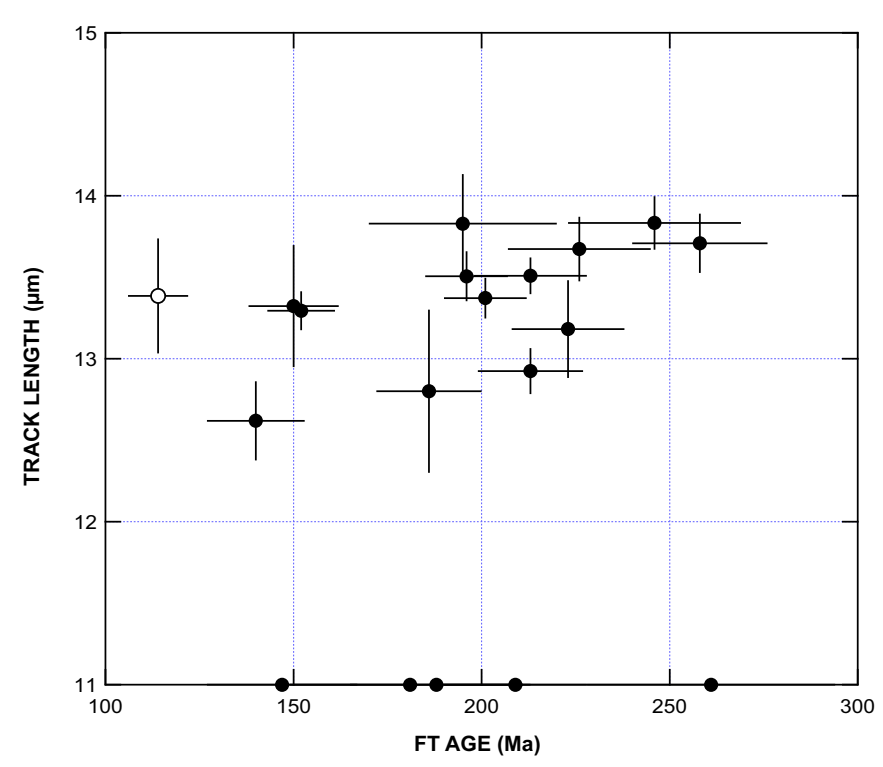

Fig. 3. Length and age data for the Brabant and Ardenne massifs from this study. No track length is available for data on the X-axis; empty dot corresponds to the sample from the Anzin borehole.

number of counted tracks might detract from our conclusions, but our track length data are coherent with data already published. The modeling strategy was to input constraints progressively to get a good agreement between data and model (Fig. 5). These constraints correspond to stratigraphic, geodynamic or weathering evidences of age:

- the Visean age (345 Ma) of volcanic ash-beds, when these samples are analyzed, and their presence at the surface at the time of their deposition (Delcambre, 1996);

- the Ardenne Paleozoic rocks were close to the surface (20 $40^{\circ} \mathrm{C}$ ) during the Late Permian-Triassic after the postCarboniferous inversion. Late Permian-Triassic sedimentary rocks still crop out in Belgian "Lorraine" and in the Malmédy Graben (Fig. 1). This hypothesis is debatable, though, and will be discussed later in the text;

- the presence of the Ardenne basement at surface during the Early Cretaceous (140-120 Ma). This assumption is supported by dating of weathering profiles.

\subsection{Present-day average temperature of $10^{\circ} \mathrm{C}$ for the outcropping samples}

Robust modelings are presented in Figure 6 for samples with the measurement of more than 85 tracks. Moreover, assuming that the track length distribution is unimodal, Rahn and Seward (2000) and Barbarand et al. (2003a) have shown that track length data do not evolve from 50 to 100 tracks. We therefore consider that modelings presented in Figure 6 may be used with confidence.

Modeling results using these constraints are good (pink envelope) or acceptable (green envelope) with a value of the Kolmogorov-Smirnov test $(\mathrm{KS})>0.80$ or 0.5 respectively (Press et al., 1988; Ketcham, 2005). The history can be summarized in two cycles of temperature rise and fall: (1) Late Carboniferous/Permian and beginning of the Triassic, and (2) Early and Middle Jurassic/Late Jurassic and Early Cretaceous (Fig. 5).

\section{Discussion}

Thermal history modeling suggests for the Late Paleozoic and the Mesozoic two episodes of cooling: Permian-Early Triassic and Late Jurassic - Early Cretaceous and two events of heating (Carboniferous and Early/ Middle Jurassic). These conclusions are supported by apatite fission-track data but also by independent geological data.

A default history can be reconstructed for the Late Paleozoic as temperatures higher than those investigated by the FT system in apatite crystals existed. The temperature increase at the end of the Paleozoic is well-established and corresponds to thrusting and thickening occurring during the Variscan orogeny leading to Carboniferous sedimentation in the coal foreland basin (Paproth et al., 1983). Synorogenic burial metamorphism was dated between 336 and $298 \mathrm{Ma}$ by the K/ Ar method for the Devonian and Carboniferous units of the Ardenne Allochton (Piqué et al., 1984). Paleotemperatures determined by illite crystallinity (Larangé, 2002), conodont coloration index (Helsen, 1995) and zircon fission tracks (Brix, 2002) suggest much higher temperatures than the track stability in apatite. These data suggest then that apatite fissiontrack data have been totally reset at that time. This flysch cover crops out today in the Para-autochthonous tectonic wedges (it can be up to $900 \mathrm{~m}$ thick in the centre of HSM-OTS, Fielitz and Mansy, 1999) but it probably previously covered a part of the Brabant. Paleotemperature estimates of this event using our data represent probably a minimum.

\subsection{Mesozoic thermal history}

Significant cooling during Permian-Triassic times is recorded by the samples which display a FT age higher than $200 \mathrm{Ma}$ (samples BEL37, BEL36, BEL35, BEL34, BEL28, BEL27). For younger samples, modeling of this cooling is not robust as the pre-Triassic history cannot be reconstructed as fission tracks have been further severely annealed. This Permian-Triassic cooling is also constrained by the hypothesis that samples were close to the surface $\left(20-40^{\circ} \mathrm{C}\right)$ during Triassic times. These temperatures correspond to the thermal domain in which fission-track are not affected by temperatures. Assuming a paleogradient of $20-40^{\circ} \mathrm{C} / \mathrm{km}$ and a surface temperature of $\sim 20^{\circ} \mathrm{C}$, samples present today at surface might have been buried at $\sim 500-1000$ meter depths. The following elements are proposed to justify this hypothesis. Morphology of the Ardenne and Brabant Massif is difficult to establish at the end of the Paleozoic but it might correspond to a peneplain with a minor relief where locally Triassic sedimentation occurred. Triassic deposits are lacking on top of the Brabant and in the extreme north of France. On the western side of the Ardenne, south of the Rocroi High, Triassic deposits correspond to playa deposits associated with low relief (Debrabant et al., 1992). Triassic deposits are preserved locally in the north east of the Paris Basin, in the Luxembourg gulf, in 

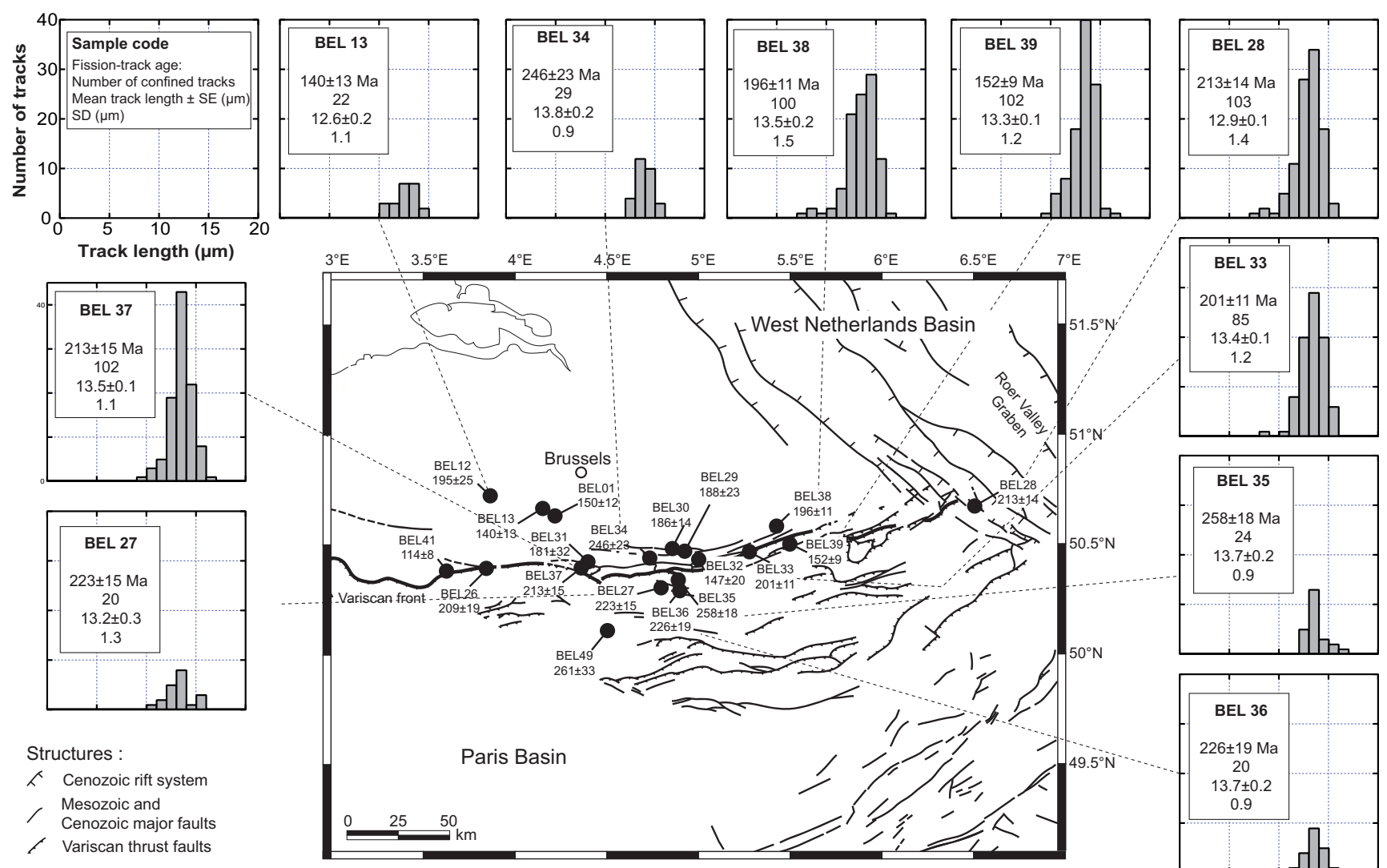

Structures :

S Cenozoic rift system

Mesozoic and

Cenozoic major faults

Variscan thrust faults

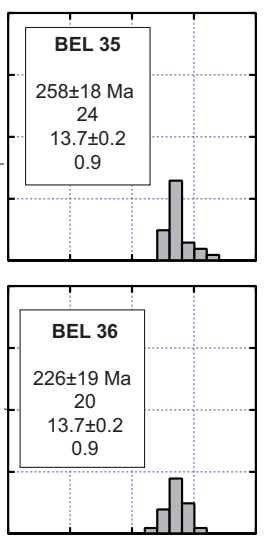

Fig. 4. Geographical distribution of the FT results of the northern Ardenne and Brabant Massifs. Histograms show confined track-length distributions: $y$-axis: frequency of tracks; $x$-axis: length in $\mu \mathrm{m}$; text from the top: sample code; AFT age \pm standard deviation; number of measured tracks; mean track length \pm standard deviation (both in $\mu \mathrm{m}$ ).

the Eifel Depression, in eastern Ardenne and in the West Netherlands Basin (see Mesozoic-Cenozoic geological history). During early Triassic, paleogeography of western Europe at this period envisages the Paris Basin as the western end of the German Basin (Péron et al., 2005). Paleocurrent directions obtained from fluvial facies indicate a mainly eastward flow, the source being the Armorican Massif (Durand, 1978). Facies maps built for the Bundsandstein show that the more proximal facies represented by conglomerates are deposited on the western edge and evolve laterally eastward to sandstone deposits (Bourquin et al., 2006). Ardenne Massif did not represent at that time the main source of detrital materials deposited in the Paris and German Basins. As soon as Muschelkalk, marine influences are recorded with very low input of detrital materials. The former Triassic surface cannot be deduced directly from these Triassic outcrops but onlapping of the Lower Jurassic deposits in the Luxembourg gulf characterizes a very flat morphology of the Ardenne Massif (Schintgen and Förster, 2013), which is not compatible with a contrasted evolution of the borders and the centre of the massif during Triassic times. We considered then that these observations attest for minor erosion $(<1000 \mathrm{~m})$ of the Paleozoic cover after Triassic times.

This Permian-Triassic cooling is followed by a Lower and Middle Jurassic temperature increase suggested by the modeling. Maximum temperature is varying between samples but is generally low $\left(\sim 50-80^{\circ} \mathrm{C}\right)$. For sample BEL 39 , the best model of thermal history corresponds to higher temperature than the other samples during the Jurassic. The same observation was done by Glasmacher et al. (1998) but for samples close to ore deposits. This younger sample is observed close to the "Midi" Fault where fluid circulation at a temperature of $110^{\circ} \mathrm{C}$, forming Mississippi Valley Type $\mathrm{Pb}$ Zn deposits, is observed (Verviers area; Heijlen et al., 2001). Similar deposits in the nearby Eifel have been dated at $170 \pm 4 \mathrm{Ma}$ by $\mathrm{Rb}-\mathrm{Sr}$ on sphalerites (Schneider et al., 1999). Thus, the modeling of sample BEL 39 involves a high temperature during the Early Jurassic, which is compatible with such local hot fluid circulation. In general, inverse modeling requires a maximum temperature increase of 50 $80^{\circ} \mathrm{C}$ depending on the samples. Although this temperature corresponds to the lower limit of the apatite fission-track annealing domain $\left(60-110^{\circ} \mathrm{C}\right)$, we considered it significant as it is observed for all the samples. The present-day geothermal gradient is averaged in the Netherlands and French sedimentary basins (mostly Paris Basin) at $29-30^{\circ} \mathrm{C} / \mathrm{km}$ (Ramaekers, 1991; Bonté et al., 2010). Assuming a surface temperature of $20{ }^{\circ} \mathrm{C}$ during Jurassic, Lower and Middle Jurassic maximum overburial may be estimated between 650 and $2000 \mathrm{~m}$. This value represents a crude estimate which might be compared with the thickness of Jurassic sedimentary units observed today in the basins (see below). Conversion of temperature into rock thickness is tedious, as it requires determining the former 

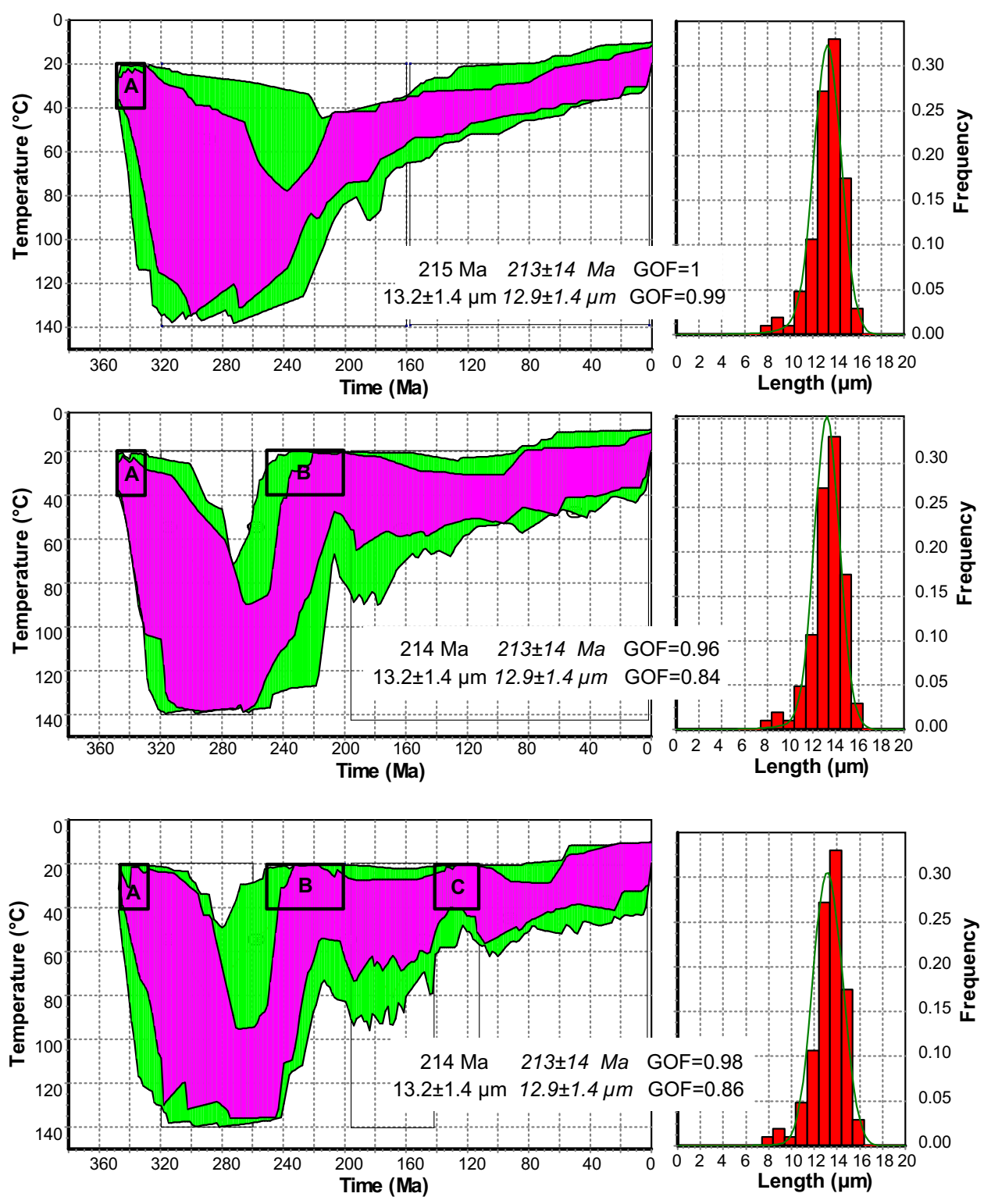

Fig. 5. Presentation for sample BEL28 of the different steps of the thermal modelling using AFTSolve ${ }^{\circledR}$. First step considers only that sample is at surface during the Visean and today. Second step introduced that sample is close to the surface $\left(20-40^{\circ} \mathrm{C}\right)$ during the Triassic. Last step considers that sample is close to the surface also during the Early Cretaceous. Numbers correspond to the measured (in italic) and modeled FT age and mean track length. GOF (goodness of fit) is an indicator of the match between the measured data and the data in agreement with the modeled thermal history (for perfect match, $\mathrm{GOF}=1$ ). Histograms correspond to the measured mean confined track length distributions; green lines attached to these histograms correspond to modeled distributions.

heat flux, thermal conductivity of vanished rocks and surface temperature. Other mechanisms than erosion might be also considered but cannot be applied to all the samples. Large heat flux increase is difficult to envisage as no remnant of high volcanic activity is observed. As discussed earlier, hot fluids may have affected the fission-track system but only locally, in particular for samples close to the Variscan front.

Our new thermal history is slightly different from the models proposed by previous thermochronological data on the Ardenne Massif (Fig. 7). Based on Late Palaeozoic samples covering the Ardenne Massif, Xu et al. (2009) suggested a
Permian-Triassic cooling episode but followed by an unique slow cooling up to the Eocene. Glasmacher et al. (1998) studying Devonian sandstone samples from the eastern Ardenne Massif (Linksrheinisches Schiefergebirge) pointed out that the area had recorded high temperatures $\left(>110^{\circ} \mathrm{C}\right)$ during the Carboniferous followed by a Mesozoic cooling with two stages: slow cooling up to $120 \mathrm{Ma}$ and faster cooling between 120 and $80 \mathrm{Ma}$. The study of a Permian sample from the Malmedy Graben suggested an alternative local history with rapid heating during the Permian and Triassic followed by a similar cooling history during the rest of the Mesozoic 

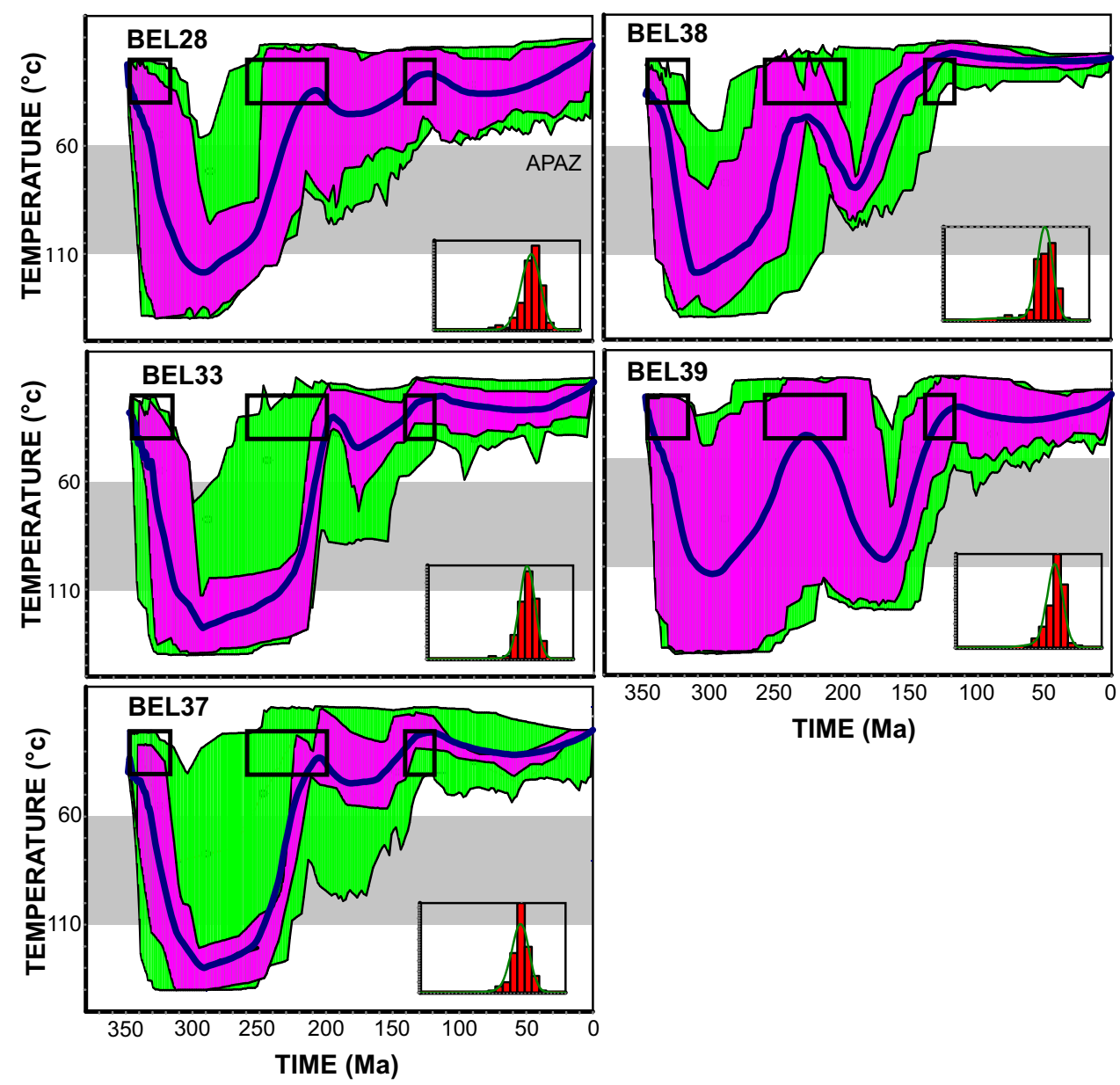

ME (Ma)

Fig. 6. Results of the thermal modelling with AFTSolve ${ }^{\circledR}$ (Ketcham, 2005) carried out on the samples with more than 85 confined tracks counted. Modelling results are displayed in a time-temperature diagram (left) and frequency distribution (right) of measured confined track length. Results in the $\mathrm{t}-\mathrm{T}$ diagram are indicated by two different reliability levels: green envelopes indicate acceptable fit; pink envelopes indicate good fit; APAZ - apatite partial annealing zone; GOF is an indicator of the goodness of fit: statistical comparison of the measured input data (age and fission-track length) and modelled output data, where a "good" result corresponds to a value of 0.5 or higher, "the best" result corresponds to a value of 1 . The squares represent the constraints applied to the modeling and are discussed in the text. Blue lines are weighted mean paths averaged at each time.

(Glasmacher et al., 1998). Van den Haute and Vercoutere (1989) concluded that the southern border of the Brabant Massif records a cooling phase during Jurassic times from temperatures higher than $100^{\circ} \mathrm{C}$ to ambient temperatures. Vercoutere and Van den Haute (1993) extended the studied area and identified that this event was also recorded for the Hercynian basement to the south. Bour (2010) proposed a preliminary fission-track study based on the same samples than those used in this study. This author suggested a Jurassic to Upper Cretaceous cover on the Ardenne.

\subsection{Mesozoic geological history: Jurassic deposition}

The presence of a Lower and Middle Jurassic cover on the Brabant and the northern Ardenne massifs is coherent with independent sedimentological arguments. Marine Liassic rocks close to the Ardenne Massif in the Paris Basin correspond to a significant bathymetry, without any particular detrital contribution nor any littoral evidence (Garcia et al., 1996; Thiry-Bastien et al., 2000). Clastics influx is only observed during the Hettangian and Sinemurian with the deposition of the Luxembourg Sandstone Formation in a tidal influenced deltaic environment (Van den Bril and Swennen, 2009). The Dogger platform (Bajocian-Bathonian) located directly close to the Ardenne Massif (from Hirson to Sedan) is characterized by oolithic, shell-rich and sub-chalky limestones which are related to environments representing inner and outer carbonate platform (Fischer, 1979). This platform follows the Liassic series after the break of the Aalenian unconformity. The thickness of this platform is decreasing towards the NW in the Boulonnais area where it is deposited directly on the Palaeozoic basement (Vidier et al., 1995). In the Boulonnais area, the absence of Liassic strata may be due either to nondeposition or to erosion before the Middle Jurassic (Mansy et al., 2003). The borehole A901 located close to CharlevilleMézières goes through a thick series of Jurassic strata with a thickness of $870 \mathrm{~m}$ ( $\sim 600 \mathrm{~m}$ of Lias and Dogger) (Debrabant et al., 1992). A geological cross-section across the northwestern part of the Paris Basin supports these observations and shows that the thicknesses of the Jurassic series, in particular 

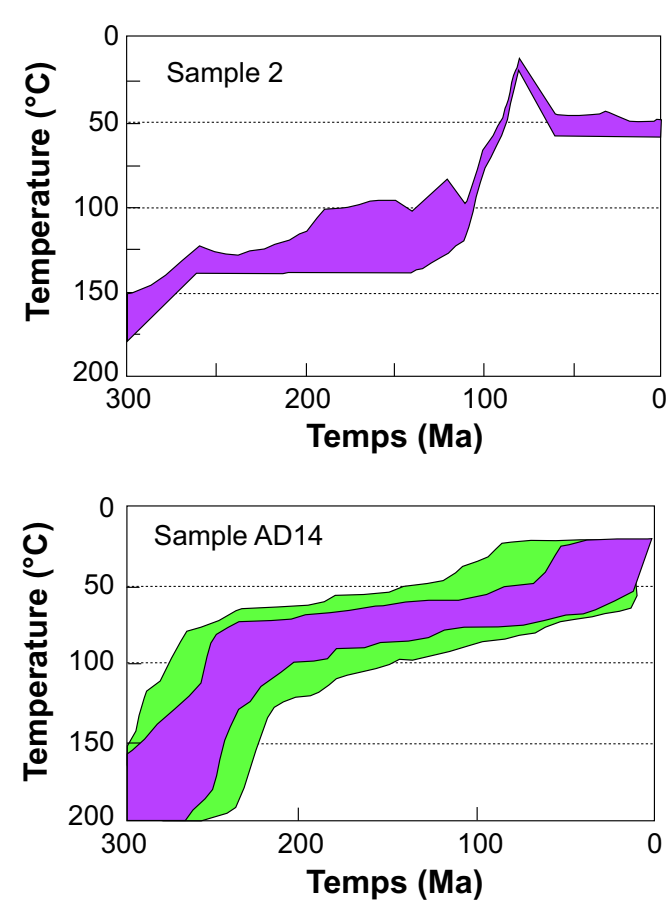

Fig. 7. Thermal histories proposed by Glasmacher et al. (1998) (A) and Xu et al. (2009) (B) respectively for the Rhenish Massif and the Ardenne Massif using apatite fission-track data.

for the Liassic and Dogger, do not reduce towards the Ardenne Massif and do not display any pinch-out (Fig. 8). Their limits rather correspond to erosion truncations interrupting the original continuity of the series.

On the other side of the massifs, in the Campine area, thick $(>450 \mathrm{~m})$ Jurassic deposits are also observed in drill-holes (Dusar et al., 2001). In the West Netherlands Basin, a significant Jurassic (Altena Group, Lias and Dogger) exists with a mean thickness of $\sim 1 \mathrm{~km}$ (Duin et al., 2006). In the British Isles, facies succession during the Jurassic shows a similar evolution (Hesselbo, 2008). Especially for the Early Jurassic and early Middle Jurassic, successions show some strong similarities at the scale of ammonite zones between widely separated basins (Hesselbo, 2008). The Jurassic is characterized mostly by fully marine environments, especially in the South, (London Platform and Wessex Basin which are the closest sedimentation areas from the Ardenne and Brabant massifs). Detrital inputs are recorded with sandy facies during several intervals, for example the Late Pliensbachian (Macquaker and Taylor, 1996; sand-rich mudstone with 5\% of sand), the Late Toarcian (Morris et al., 2006) and the Oxfordian, but always in marine conditions as illustrated by shoreface sands during the Late Toarcian (Hesselbo, 2008). High thickness may have been deposited in the Weald Basin as well, where more than $1500 \mathrm{~m}$ of Jurassic are preserved (Chadwick, 1986).

The situation may have changed during the Late Jurassic and various factors argue for the existence of terrestrial conditions or inputs into the marine realm: (1) the origin of the detrital particles accumulated in the Callovian-Oxfordian clays in the Bure area of the eastern Paris Basin has been determined as NNW-SSE from magnetic susceptibility data
(Esteban et al., 2006) and (2) sandy limestones are observed in the Malm of the eastern border of the Paris Basin as well as on the edge of the West Netherlands Basin.

Based on these data, it may be interpreted that the Paris Basin and the West Netherlands Basin were much more widespread than their current geometry suggests. The geological contacts between the Mesozoic sedimentary cover and the Ardenne Massif thus correspond to a limit of erosion.

\subsection{Stability of the Ardenne and Brabant massifs revisited}

The Brabant and Ardenne massifs have been depicted as a positive structure which was clear of sediments during most of the Mesozoic and was considered as stable throughout the Mesozoic (Ziegler, 1990; Dercourt et al., 2000). The Brabant Massif is part of a larger massif, the Anglo-Brabant Massif or the London-Brabant Massif (LBM), which has formed a positive structural element since the mid-Devonian (Rijkers et al., 1993). As a consequence, the Caledonian basement lies at relatively shallow depth across the massif, encompassing a large area of southern Britain, the southern North Sea, southern Netherlands, Belgium and northern France. Based on geophysical studies, the onlapping pattern of sediments of Late Paleozoic, Mesozoic and Cenozoic ages shows that the LBM has been tectonically stable since Devonian times (Rijkers et al., 1993; Rijkers and Duin, 1994).

This study shows however that significant, although relatively minor, vertical movements are recorded for this domain during the Mesozoic and questions its relative stability (Fig. 9). Since the breakup of Pangea, the European continent has undergone several episodes of uplift (Ziegler, 1987). Most of the constraining data are coming from the sedimentary records in inverted basins. Four main episodes are well characterized by erosion surface and/or non-deposition and unconformity. A regional event known as the Middle Jurassic thermal dome or mid-Cimmerian event is recorded at the transition between Toarcian and Aalenian and characterized a large domain centered in the North Sea where erosion occurred (Ziegler, 1990; Underhill and Partington, 1993). Unconformities at the transition between the Jurassic and the Cretaceous and in the Berriasian (Late Cimmerian phases) are evidenced in the Paris Basin (Guillocheau et al., 2000), in the West Netherlands Basin (Nelskamp et al., 2008), in sub-basins from the North Sea (Broad Fourteens, Van Wijhe, 1987) and at larger scale in the Central European Basin System (Mazur and Schek-Wenderoth, 2005). The dominant uplift event (Laramide phase) affecting Europe occurred during the Late Cretaceous and Middle Paleocene when many Paleozoic and Mesozoic rifts and basin structures in the interior of the European continent underwent inversion (Ziegler, 1987). A last main inversion phase generally referred as the Pyrenean phase took place during Bartonian-Priabonian times and is recorded in the southern border of the North Sea area and in Belgium (Deckers et al., 2016; Parrish et al., 2018; Deckers and Matthijs, 2017).

Our FT data combined with geological constraints illustrate than the main phase of inversion recorded in the Brabant and the Ardenne massifs corresponds to the LateCimmerian phase. This conclusion agrees with the previous 


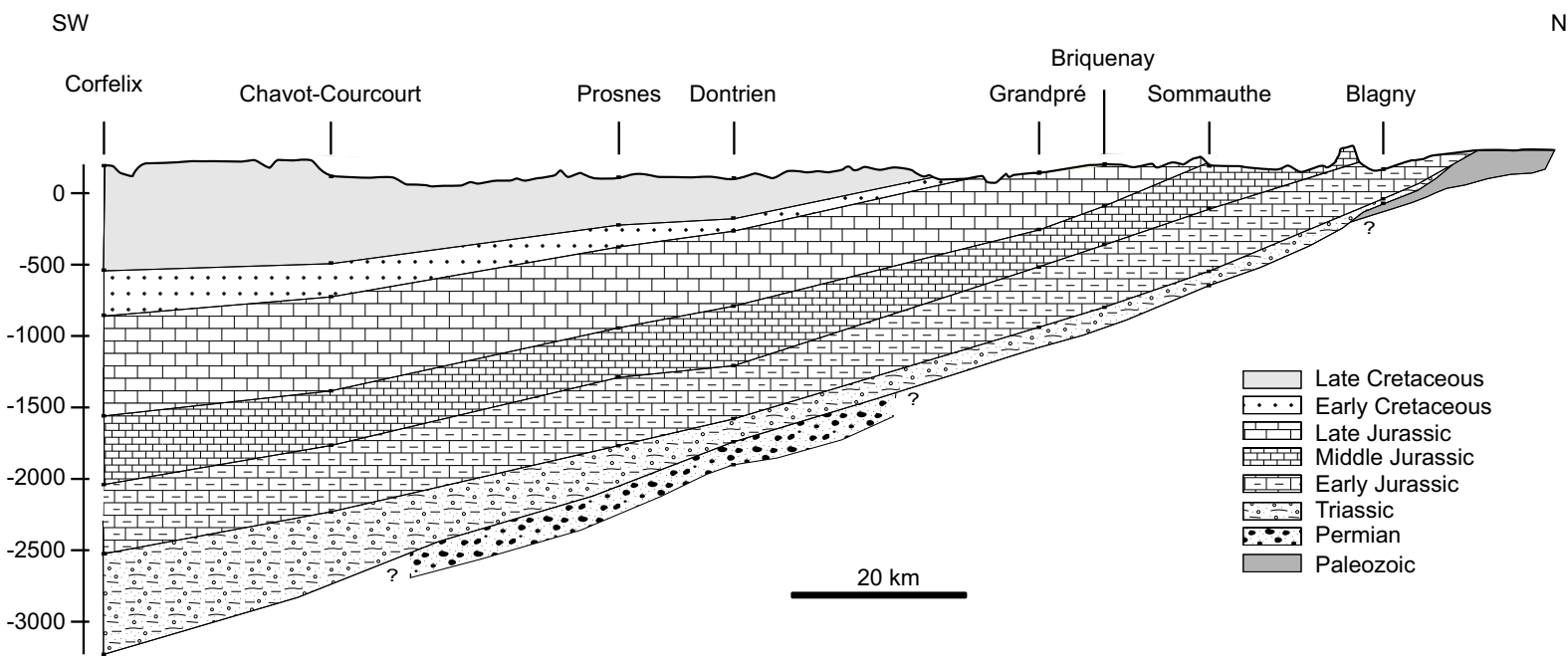

Fig. 8. Regional cross section across the northeastern Paris Basin towards the Ardenne Massif. Data are from the BSS database (BRGM) and names correspond to the considered boreholes. The profile is localized in Figure 1.

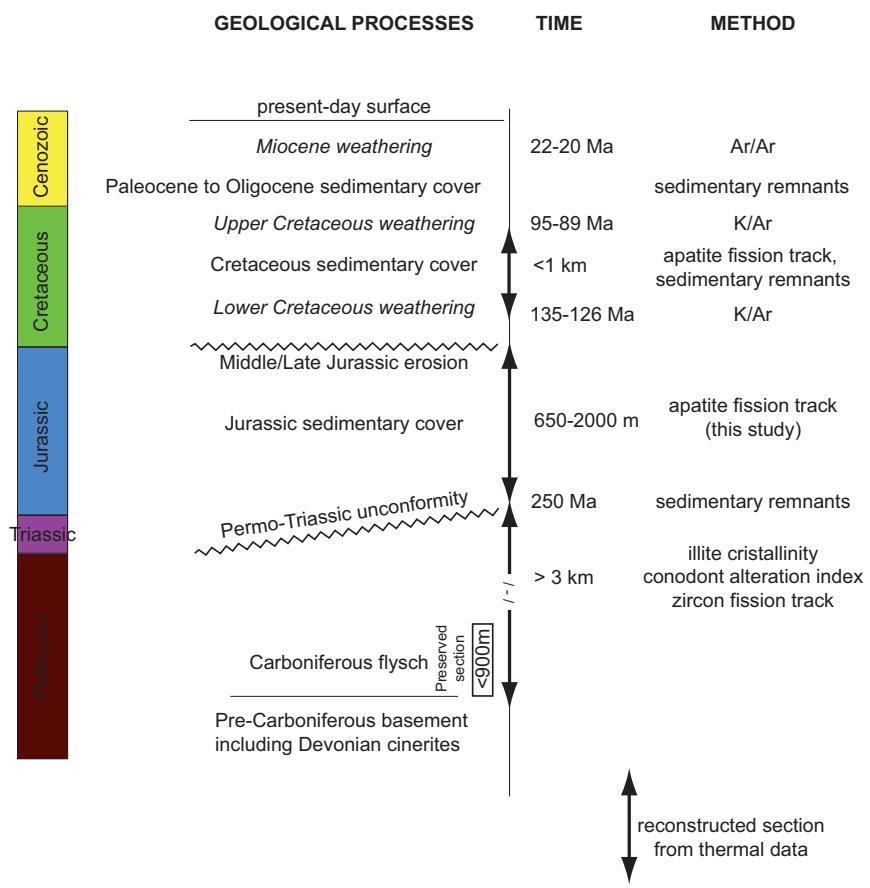

Fig. 9. Schematic evolution of the Ardenne massif considering sedimentation, erosion and weathering periods.

studies of Vercoutere and van den Haute (1993). This Upper Jurassic uplift of the London-Brabant Massif has already been suggested by Ziegler (1990). On the contrary, the midCimmerian event is recorded in the Paris Basin close to the studied area (Debrabant et al., 1992; Mansy et al., 2003) and at distance (Guillocheau et al., 2000) but is not recorded by the thermal data. This is probably due to the amount of erosion associated, which is far below the resolution of FT method. Inversion at the limit between the Jurassic and the Cretaceous is the main event detected by our data. The Laramide and Pyrenean phases are also not recorded by our data, indicating that for the Brabant and the Ardenne massifs, vertical movements are minor and not detected.

After this inversion, during the Early Cretaceous, terrestrial conditions prevail in the Ardenne Massif as indicated by deep weathering (Dupuis, 1992; Demoulin, 1995; Yans, 2003a, b; Quesnel et al., 2006; Demoulin et al., 2018) but also in the Paris Basin and its other bordering basements (Thiry et al., 2006). The Borne de Fer ferricrete is observed on top of the Marnes de Longwy (Early Bajocian) close to Luxembourg (Quesnel et al., 2003; Théveniaut et al., 2007). It corresponds to an indurated saprolite of highly siliceous origin, which has been dated using paleomagnetism as Early Cretaceous (Théveniaut et al., 2007). Detailed studies of Dogger sedimentary units from the eastern Paris Basin also show that circulation of meteoric fluid is associated with an episode of terrestrial hydrological refill (Vincent et al., 2007; Brigaud et al., 2009). In the West Netherlands Basin, this interval is characterized by a main unconformity at the base of the Valanginian (Rijnland Group) (Duin et al., 2006). At a global scale, Western Europe is characterized during the Early Cretaceous by terrestrial conditions (Thiry et al., 2006).

\section{Conclusion}

The apatite fission-track data of this study suggest a new post-Variscan exhumation scenario of the Ardenne and Brabant Massifs assuming geological, sedimentological and paleoweathering constraints. This scenario is strictly controlled by these constraints which are required limits for thermochronological data interpretation.

After burial of the pre-Carboniferous basement under a Carboniferous flysch estimated to be $3 \mathrm{~km}$ thick, the basement was eroded following a generalized uplift of the Variscan chain. The Ardenne Massif was then a terrestrial environment with erosion and the probable deposition of Triassic fluvial sediments similar to those observed in the northeastern Paris Basin. After the Hettangian, the area experienced marine 
conditions with the deposition of Lower and Middle Jurassic strata. This cover may be estimated between 650 and $2000 \mathrm{~m}$ thick depending on the paleothermal hypotheses and sample location. Preserved Jurassic series in the nearby sedimentary basins (Paris Basin, West Netherlands Basin, Wessex Basin) are consistent with the low thickness value of this cover. The area has been then eroded from the Late Jurassic to the Early Cretaceous and terrestrial conditions prevail again in the Ardenne and Brabant massifs with the formation of thick kaolin deposits but also in the Paris Basin with the deposition of the mainly fluvial Wealden facies and the development of laterites and ferricretes. This inversion event has been recorded in the nearby Paris Basin and West Netherlands Basin by a regional unconformity capped by Valanginian deposits. Further evolution of the area cannot be studied using paleotemperature data which remain low $\left(<50^{\circ} \mathrm{C}\right)$ during the Late Cretaceous and the Tertiary. Our results question the relative stability of the Paleozoic massifs and the connections between sedimentary basins. They moreover illustrate that these massifs shared a similar history with nearby sedimentary basins during almost all the Mesozoic.

Acknowledgements. I.B. thanks T. Mortier, P. Spagna and J.M. Baele for field assistance and for providing samples from the collection of the University of Mons. This work was funded by the BRGM Research Division through the CANEV Program, "Géodynamique des envelopes superficielles" and "Géologie de la Surface" Research Projects, and by a scientific partnership between Paris Sud University and the BRGM via the "Thermochronologie traces de fission sur apatite des domaines de socle de France et de Belgique" project.

\section{References}

Barbarand J, Lucazeau F, Pagel M, Séranne M. 2001. Burial and exhumation history of the south-eastern Massif Central (France) constrained by an apatite fission-track thermochronology. Tectonophysics 335: 275-290.

Barbarand J, Hurford T, Carter A. 2003a. Variation in apatite fissiontrack length measurement: implications for thermal history modelling. Chemical Geology 198(1-2): 77-106.

Barbarand J, Carter A, Wood I, Hurford AJ. 2003b. Compositional and structural control of fission-track annealing in apatite. Chemical Geology 198(1-2): 107-137.

Barbarand J, Quesnel F, Pagel M. 2013. Lower Paleogene denudation of the Upper Cretaceous cover of the Morvan massif and southeastern Paris Basin (France) revealed by AFT thermochronology and paleoweathering study. Tectonophysics 608: 1310-1327.

Barbier F. 2012. Étude de paléoaltération météorique (Crétacé Inférieur à Néogène) sur socle silicoclastique hétérogène: caractérisation et essai de cartographie d'altérites en Région Wallonne (Belgique). Unpublished $\mathrm{PhD}$ thesis, University of Namur, 437 p.

Belanger I, Delaby S, Delcambre B, Ghysel P, Hennebert M, Laloux M, et al. 2012. Redéfinition des unités structurales du front varisque utilisées dans le cadre de la nouvelle Carte géologique de Wallonie (Belgique). Geologica Belgica 153(3): 169-175.

Bless MJ, Felder PJ. 1989. Note on the Cretaceous of Hockaï (Hautes Fagnes, NE Belgium). Annales de la Société géologique de Belgique 112: 47-56.

Bless MJM, Demoulin A, Felder PJ, Jagt JWM, Reynders JPH. 1991. The Hautes Fagnes area (NE Belgium) as a monadnock during the
Late Cretaceous. Annales de la Société Géologique de Belgique 113: 75-101.

Bonté D, Guillou-Frottier L, Garibaldi C, Bourgine B, Lopez S, Bouchot V, et al. 2010. Subsurface temperature maps in French sedimentary basins: new data compilation and interpolation. Bull Soc géol Fr 181(4): 377-390. DOI: 10.2113/gssgfbull.181.4.377.

Boulvain F, Vandenberghe N. 2018. An Introduction to the Geology of Belgium and Luxembourg. In: Demoulin A, ed. Landscapes and Landforms of Belgium and Luxembourg. Cham (Suisse): Springer, pp. 9-33.

Boulvain F, Belanger I, Delsate D, Ghysel P, Godefroit P, Laloux M. et al. 2001. Triassic and Jurassic lithostratigraphic units (Belgian Lorraine). Geologica Belgica 4(1-2): 113-119.

Bour I. 2010. Histoire thermique des massifs ardennais et bohémien : conséquences sur la dynamique de l'Europe de l'Ouest au MésoCénozoïque. PhD thesis, University Paris Sud, 363 p.

Bourquin S, Péron S, Durand M. 2006. Lower Triassic sequence stratigraphy of the western part of the Germanic Basin (west of Black Forest): Fluvial system evolution through time and space. Sedimentary Geology 186: 187-211.

Braun J., 2010. The many surface expressions of mantle dynamics. Nature Geosciences 3(12): 825-833.

Briart A. 1888. Notice descriptive des terrains tertiaires et crétacés de l'Entre-Sambre-et-Meuse. Mém Soc Géol Belgique 15: 3-58.

Brigaud B, Durlet Ch, Deconinck J-F, Vincent B, Thierry J, Trouiller A. 2009. The origin and timing of multiphase cementation in carbonates: Impact of regional scale geodynamic events on the Middle Jurassic Limestones diagenesis (Paris Basin, France). Sedimentary Geology 222: 161-180.

Brix MR. 2002. Thermal history of Palaeozoic rocks in the Meuse Valley between Charleville-Mézières and Namur (France, Belgium) assessed from zircon fission-track data. Aardk Mededel 12: 93-95.

Brunet M-F., Le Pichon X. 1982. Subsidence of the Paris Basin. Journal of Geophysical Research B 87: 8547-8560.

Bultynck P, Geukens F, Smolderen A. 2001. Permian lithostratigraphic units, Malmédy Graben (Belgium). Geologica Belgica 4 (1-2): 105-106.

Burtner RL, Nigrini A, Donelick RA. 1994. Thermochronoloy of Lower Cretaceous source rocks in the Idaho-Wyoming thrust belt. Am Ass Petr Geol Bull 78(10): 1613-1636.

Chadwick RA. 1986. Extension tectonics in the Wessex Basin, southern England. Journal of the Geological Society, London 143: 465-488.

Chantraine J, Autran A, Cavelier C. 2003. Carte géologique de la France à $1 / 1000000,6^{\mathrm{e}}$ édition révisée. Orléans : BRGM.

Cloetingh S, Burov E. 2011. Lithospheric folding and sedimentary basin evolution: a review and analysis of formation mechanisms. Basin Research 23: 257-290.

Debrabant P, Chamley H, Deconinck J-F, Récourt Ph, Trouiller A. 1992. Clay sedimentology, mineralogy and chemistry of Mesozoic sediments drilled in the Northern Paris Basin. Scientific Drilling 3: $138-152$

Deckers J, Matthijs J. 2017. Middle Paleocene uplift of the Brabant Massif from central Belgium up to the southeast coast of England. Geol Mag 154(5): 1117-1126. DOI: 10.1017/S001675681600073X.

Deckers J, Vandenberghe N, Lanckacker T, de Koninck R. 2016. The Pyrenean inversion phase in northern Belgium: an example of a relaxation inversion? Int J Earth Sci (Geol Rundsch) 105: 583-593.

Delcambre B. 1996. Application de la typologie du zircon à la téphostratigraphie du Carbonifère de la Belgique et des régions limitrophes. Thèse de doctorat. Université Catholique de Louvain, $318 \mathrm{p}$. 
Demoulin, A., 1995. Les surfaces d'érosion méso-cénozoïques en Ardenne-Eifel. Bull Soc géol Fr 166(5): 573-585.

Demoulin A, Quesnel F, Dupuis C, Gerrienne P, Yans J. 2010. Cenomanian sands and clays north of the Vesdre valley: the oldest known Cretaceous deposits in eastern Belgium. Geologica Belgica 11(3): 241-256.

Demoulin A, Barbier F, Dekoninck A, Verhaert M, Ruffet G, Dupuis C, et al. 2018. Landscapes and Landforms of Belgium and Luxembourg. In: Demoulin A, ed. Landscapes and Landforms of Belgium and Luxembourg. Cham (Suisse): Springer Verlag, pp. 63-84.

Demyttenaere R, Laga P. 1988. Breuken- en isohypsenkaarten van het Belgisch gedeelte van de roerdal slenk. Professional Paper 1988/4, $\mathrm{n}^{\circ}$ 234. Brussels: Belg. Geol. Dienst.

Dercourt J, Gaetani M, Vrielynck B, Barrier E, Biju-Duval B, Brunet MF, et al. (eds). 2000. Atlas Peri-Tethys, Paleogeographic maps. CCGM/CGMW, Paris, 24 maps and explanatory notes: I-XX; 1-269.

De Vos W, Poot B, Hus J, El Khayati M. 1992. Geophysical characterization of lithologies from the Brabant Massif as a contribution to gravimetric and magnetic modelling. Bull Soc Belg Géol 101: 173-180.

Dèzes P, Schmid SM, Ziegler PA. 2004. Evolution of the European Cenozoic Rift System: interaction of the Alpine and Pyrenean orogens with their foreland lithosphere. Tectonophysics 389: 1-33.

Duin EJT, Doornenbal JC, Rijkers RHB, Verbeek JW, Wong Th E. 2006. Subsurface structure of the Netherlands-results of recent onshore and offshore mapping. Netherlands Journal of Geosciences-Geologie en Mijnbouw 85(4): 245-276.

Dupuis C. 1992. Mesozoic kaolinized giant regoliths and Neogene halloysite cryptokarsts: two striking paleoweathering types in Belgium. In: Schmitt JM, Gall Q, eds. Mineralogical and Geochemical records of Paleoweathering, IGCP 317, ENSMP, Mém Sci de la Terre 18: 61-68.

Dupuis C, Ertus R. 1994. Neogene lacustrine deposits of karstic origin (Ardenne Massif, Belgium) in Global Geological Record of Lakes Basins. In: Gierlowki-Kordesch E, Kelt K, eds. IGCP project 324 , GLOPALS-UNESCO-IUGS, World and Regional Geology 4. Cambridge (UK): Cambridge University Press, pp. 299-302.

Dupuis C, Charlet J-M, Dejonghe L, Thorez J. 1996. Reconnaissance par carottage des paléoaltérations kaolinisées mésozoïques de la Haute Ardenne (Belgique). Le sondage de Transinne (194E-495) : premiers résultats. Ann Soc Géol Belgique 2: 91-109.

Dupuis C, Nicaise D, De Putter T, Perruchot A, Demaret M, Roche E. 2003. Miocene cryptokarsts of Entre-Sambre-et-Meuse and Condroz plateaus. Paleoenvironment, evolution and weathering processes. Géologie de la France 2003(1): 27-31.

Durand M. 1978. Paléocourants et reconstitution paléogéographique : l'exemple du Buntsandstein des Vosges méridionales (Trias inférieur et moyen continental). Sciences de la Terre, Nancy 22(4): 301-390.

Dusar M, Lagrou D. 2007. Cretaceous flooding of the Brabant Massif and the lithostratigraphic characteristics of its chalk cover in Northern Belgium. Geologica Belgica 10(1-2): 27-38.

Dusar M, Langenaeker V, Wouters L. 2001. Permian-Triassic-Jurassic lithostratigraphic units in the Campine basin and the Roer Valley Graben (NE Belgium). Geologica Belgica 4(1): 107-112.

Ertus R. 1990. Les néoformations d'halloysite dans les cryptokarsts oligo-miocènes de l'Entre-Sambre-et-Meuse (Belgique). Approche sédimentologique, pétrographique et minéralogique. Thèse de doctorat, Université de Paris-sud, Centre d'Orsay, 177 p.

Esteban L, Bouchez JL, Trouiller A. 2006. The Callovo-Oxfordian argillites from eastern Paris Basin magnetic data and petrofabrics. CR Geoscience 338: 12-13.

Færseth RB. 1996. Interaction of Permo-Triassic and Jurassic extensional fault-blocks during the development of the northern
North Sea. Journal of the Geological Society, London 153: 931-944.

Felder PJS. 1994. Late Cretaceous (Santonian-Maastrichtian) sedimentation rates in the Maastricht (NL), Liège/Campine (B) and Aachen (D) area. Annales de la Société Géologique de Belgique 117(2): 311-319.

Fielitz W, Mansy J-L. 1999. Pre- and synorogenic burial metamorphism in the Ardenne and neighbouring areas (Rhenohercynian zone, central European Variscides). In: Sintubin M, Vandycke S, Camelbeeck T, eds. Palaeozoic to recent tectonics in the $\mathrm{NW}$ European Variscan front zone. Tectonophysics 309: 227-256.

Fischer J-C. 1979. Le Jurassique moyen au SW du massif ardennais : essai de synthèse biosédimentologique. In: Symposium sédimentation Jurassique W européen, ASF Publication spéciale $\mathrm{n}^{\mathrm{o}} 1$, 47-54.

Galbraith RF, Laslett GM. 1993. Statistical models for mixed fissiontrack ages. Nucl Tracks Radiat Meas 21: 459-470.

Garcia JP, Dromart G, Guillocheau F, Allemand P, Gaumet F, Robin C, et al. 1996. Bathonian-Callovian Paris Basin-Subalpine Basin intercorrelations along an Ardenne-Ardèche cross-section. Comptes Rendus de l'Académie des Sciences de Paris 323: 697-703.

Glasmacher UA, Zentilli M, Grist AM. 1998. Apatite fission-track thermochronology of Paleozoic sandstones and the Hill-intrusion, northern Linksrheinisches Schiefergebirge, Germany. In: Van den Haute P, De Corte F, eds. Advances in Fission-Track Geochronology. Kluwer Academic Publishers, pp. 151-172.

Gleadow AJW. 1981. Fission-track dating methods: what are the real alternatives. Nuclear Tracks 5: 3-14.

Green PF. 1986. On the thermo-tectonic evolution of Northern England: evidence from fission-track analysis. Geological Magazine 123, 493-506.

Green PF, Duddy IR, Laslett GM, Hegarty KA, Gleadow AJW, Lovering JF. 1989. Thermal annealing of fission tracks in apatite: 4. Quantitative modelling techniques and extension to geological timescales. Chem Geol (Isot Geosci Sect) 79: 155-182.

Guillocheau F, Robin C, Allemand P, Bourquin S, Brault N, Dromart G, et al. 2000. Meso-Cenozoic geodynamic evolution of the Paris Basin: 3D stratigraphic constraints. Geodinamica Acta 13: 189-246.

Gulink M. 1963. Guide books. Excursions M-N, $6^{\mathrm{e}}$ Congrès International de Sédimentologie.

Heijlen W, Muchez P, Banks DA. 2001. Origin and evolution of high salinity, $\mathrm{Zn}-\mathrm{Pb}$ mineralising fluids in the Variscides of Belgium. Mineralium Deposita 36: 165-176.

Helsen S. 1995. Burial history of Palaeozoic strata in Belgium as revealed by conodont colour alteration data and thickness distributions. Geol Rundsch 84: 738-747.

Hesselbo SP. 2008. Sequence stratigraphy and inferred relative sealevel change from the onshore British Jurassic. Proceedings of the Geologists' Association 119: 19-34.

Hurford AJ. 1990. Standardization of fission-track dating calibration: Recommendation by the Fission-Track Working Group of the I.U. G.S. Subcommission on Geochronology. Chemical Geology: Isotope Geoscience Section 80: 171-178.

Hurford AJ, Green PF. 1983. The zeta age calibration of fission-track dating. Isotopic Geoscience 1: 285-317.

Karg H, Carter A, Brix M, Littke R. 2005. Late- and post-Variscan cooling and exhumation history of the northern Rhenish Massif and the southern Ruhr Basin: new constraints from fission-track analysis. International Journal of Earth Sciences (Geologische Rundschau) 94: 180-192.

Ketcham RA. 2005. Forward and inverse modeling of lowtemperature thermochronometry data. Rev Mineral Geochem 58: 275-314. 
Ketcham RA, Donelick RA, Donelick MB. 2000. AFTSolve: a program for multi-kinetic modeling of apatite fission-track data. Geol Mater Res 2(1): 1-32.

Ketcham RA, Carter A, Donelick RA, Barbarand J, Hurford AJ. 2007. Improved modeling of fission-track annealing in apatite. American Mineralogist 92: 799-810.

Knapp G. 1980. Erl. Geol. Kte. Der nördlichen Eifel 1: 100000. 155 p., Krefeld 3rd ed.

Lacquement F, Mansy J-L., Hanot F, Meilliez F. 1999. Retraitement et interprétation d'un profil sismique pétrolier méridien au travers du Massif paléozoïque ardennais (Nord de la France). Comptes Rendus Académie des Sciences de Paris, Sciences de la terre et des planètes 329: 471-477.

Larangé F. 2002. Low-grade metamorphism and geotectonic setting of the Brabant Massif and the Medio-occidental part of the Ardenne, Belgium: Application of white mica crystallinity, b cell dimension and transmission electron microscope studies. Thèse inédite. Université catholique de Louvain, $211 \mathrm{p}$.

Larson SA, Tullborg EL, Cederbom C, Stiberg JP. 1995. Sveconorwegian and Caledonian foreland basins in the Baltic Shield revealed by fission-track thermochronology. Terra Nova 11: 210-215.

Laslett GM, Gleadow AJW, Duddy IR. 1984. The relationship between fission-track length and density in apatite. Nucl Tracks 9: 29-38.

Legrand R. 1968. Le massif du Brabant. Mem Expl Cartes Géol Min Belg 9: 148.

Lucius M. 1948. Entstehung und Entwicklung es Luxemburger Flusssytems. Bulletin de la Société des Naturalistes Luxembourgeois 53: 17-48.

Macquaker JHS, Taylor KG. 1996. A sequence stratigraphic interpretation of a mudstone-dominated succession: The Lower Jurassic Cleveland Ironstone Formation, UK. Journal of the Geological Society, London 153: 759-770.

Mader D. 1985. Fluvial conglomerates in continental red beds of the Buntsandstein (Lower Triassic) in the Eifel (F.R.G.) and their palaeoenvironmental, palaeogeographical and palaeotectonic significance. Sedimentary Geology 44: 1-64.

Mansy JL, Everaerts M, De Vos W. 1999. Structural analysis of the Acadian and Variscan fold belts in Belgium and northern France from geophysical and geological evidence. Tectonophysics 309: 99-116.

Mansy, JL, Manby GM, Averbuch O, Everearts M, Bergerat F, Van Vliet-Lanoë B, et al. 2003. Dynamics and inversion of the Mesozoïc basin of the Weald-Boulonnais area: role of basement reactivation. Tectonophysics 373: 161-179.

Mazur S, Schek-Wenderoth M. 2005. Constraints on the tectonic evolution of the Central European Basin System revealed by seismic reflection profiles from Northern Germany. Netherlands Journal of Geosciences 84(4): 389-401.

Morris JE, Hampson GJ, Johnson HD. 2006. A sequence stratigraphic model for an intensely bioturbated shallow-marine sandstone: the Bridport Sand Formation, Wessex Basin, UK. Sedimentology 53: 1229-1263.

Nelskamp S, David P, Littke R. 2008. A comparison of burial, maturity and temperature histories of selected wells from sedimentary basins in The Netherlands. International Journal of Earth Sciences 97: 931-953.

Paproth E, Dusar M, Bless M, Bouckaert J, Delmer A, Fairon-Demaret M, et al. 1983. Bio- and lithostratigraphic subdivisions of the Silesian in Belgium. A review. Ann Soc Géol Belg 106: 241-283.

Parrish RR, Parrish CM, Lasalle S. 2018. Vein calcite dating reveals Pyrenean orogen as cause of Paleogene deformation in southern England. Journal of the Geological Society 175(3): 425-442.
Péron S, Bourquin S, Fluteau F, Guillocheau F. 2005. Paleoenvironment reconstructions and climate simulations of the Early Triassic: impact of the water and sediment supply on the preservation of fluvial system. Geodinamica Acta 18(6): 431-446.

Piqué A, Huon S, Clauer N. 1984. La schistosité hercynienne et le métamorphisme associé dans la vallée de la Meuse, entre Charleville-Mézières et Namur (Ardenne franco-belges). Bull Soc Belge Géol 93: 55-70.

Press WH, Flannery BP, Teukolsky SA, Vettering WT. 1988. Numerical Recipes in C. Cambridge (UK): Cambridge University Press, 735 p.

Quesnel F. 2006. Méso-Cénozoïque, Crétacé et Cénozoïque, 3 geological maps and $87 \mathrm{p}$ of explanatory notes. In: Lacquement $\mathrm{F}$, Quesnel F, Mansy JL, Moulouel H, Vinchon C, Gateau C et al., eds. La Géologie du territoire de l'Avesnois, Système d'information géologique, $D V D, B R G M / R P-55465-F R$. Orléans : BRGM.

Quesnel F, Théveniaut H, Voisin L, Wyns R. 2003. The "Pierres de Stonne" and the "Borne de fer", as main features of Meso-Cenozoic palaeoweathering of the Upper Lorraine and Ardennian Thiérache areas (Ardennes and Moselle departments, France), Field trip guide. In: Paleoweathering and paleosurfaces in the Ardenne-Eifel region-Preizerdaul-Luxembourg-14-17/05/2003. Géologie de la France 2003(1) (supplement): 11-28.

Quesnel F, Yans J, Dupuis C, Wyns R, Théveniaut, H Demoulin A. 2006. Mesozoic and Cenozoic paleoweathering in the Ardenne and the surrounding area. Characterisation dating and geometric reconstruction of the associated paleosurfaces and analysis of their successive deformation, Extended Abstract. Géologie de la France 1-2: 99-102, 3 figs.

Rahn M, Seward D. 2000. How many tracks do we need? On Track 20: $12-15$.

Ramaekers JJF. 1991. The Netherlands. In: Hurtig E, Cermak V, Haenel R, Zui V, eds. Geothermal Atlas of Europe. Gotha: Hermann Haack Verlagsgesellschaft mbH.

Rijkers R, Duin E. 1994. Crustal observations beneath the southern North Sea and their tectonic and geological implications. Tectonophysics 240: 215-224.

Rijkers R, Duin E, Dusar M, Langenaekerj V. 1993. Crustal structure of the London-Brabant Massif, southern North Sea. Geological Magazine 130(5): 569-574.

Robaszynski F, 2006. Maastrichtian. Geologica Belgica 9: 63-72.

Rosenbaum G, Lister GS, Duboz C. 2002. Relative motions of Africa, Iberia and Europe during Alpine orogeny. Tectonophysics 359: 117-129.

Schintgen T, Förster A. 2013. Geology and basin structure of the Trier-Luxembourg Basin-implications for the existence of a buried Rotliegend graben. Zeitschrift der deutschen Gesellschaft für Geowissenschaften 164(4): 615-637.

Schneider J, Haack U, Hein UF, German A. 1999. Direct Rb-Sr dating of sandstone-hosted sphalerites from stratabound $\mathrm{Pb}-\mathrm{Zn}$ deposits in the northern Eifel, NW Rhenish Massif, Germany. In: Stanley et al., eds. Mineral deposits: processes to processing. Rotterdam: Balkema, pp. 1287-1290.

Théveniaut H, Quesnel F, Wyns R, Hugues G. 2007. Palaeomagnetic dating of the "Borne de Fer" ferricrete (NE France): lower Cretaceous continental weathering. Palaeogeography Palaeoclimatology Palaeoecology 253: 271-279.

Thiry M, Quesnel F, Yans J, Wyns R, Vergari A, Théveniaut H, et al. 2006. Continental France and Belgium during the Early Cretaceous: paleoweatherings and paleolandforms. Bull Soc géol Fr 177: $155-175$.

Thiry-Bastien P, Thierry J, Debourse P, Vidier J-P. 2000. Géométries et profils de dépôt de la plate-forme ardennaise au Bathonien 
supérieur-Callovien inférieur: un exemple de contraintes stratigraphiques lors de l'ennoyage d'une plate-forme carbonatée. Géologie de la France 2: 3-15.

Underhill JR, Partington MA. 1993. Use of genetic sequence stratigraphy in defining and determining a regional tectonic control on the "mid-Cimmerian Unconformity" implications for North Sea basin development and the global sea-level chart. In: Weimer P, Posamentier HW, eds. Silisiclastic Sequence Stratigraphy: Recent Developments and Applications. AAPG Memoir 58: 449-484.

Vandenberghe N, Van Simaeys S, Steurbaut E, Jagt JWM, Felder PJ. 2004. Stratigraphic architecture of the Upper Cretaceous and Cenozoic along the southern border of the North Sea Basin in Belgium. Netherlands Journal of Geosciences 83: 155-171.

Van den Bril K, Swennen R. 2009. Sedimentological control on carbonate cementation in the Luxembourg Sandstone Formation. Geological Belgica 12(1-2): 3-23.

Van den Haute P, Vercoutere C. 1989. Apatite fission-track evidence for a Mesozoic uplift of the Brabant massif: preliminary results. Annales de la Société Géologique de Belgique 112(2): 443-452.

Van Wijhe DH. 1987. Structural evolution of inverted basins in the Dutch offshore. Tectonophysics 137: 171-219.

Vercoutere C, Van den Haute P. 1993. Post-Palaeozoic cooling and uplift of the Brabant massif as revealed by apatite fission-track analysis. Geological Magazine 130(5): 639-646.

Vidier J-P, Garcia J-P, Thierry J, Fauconnier D. 1995. Le Dogger du Boulonnais (Nord bassin de Paris): nouveaux découpages chronologique et séquentiel des formations carbonatées jurassiques en bordure du massif Londres-Brabant. C.R. Académie des Sciences Paris 320, série Iia, pp. 219-226.
Vincent B, Emmanuel L, Houel P, Loreau J-P. 2007. Geodynamic control on carbonate diagenesis: Petrographic and isotopic investigation of the Upper Jurassic formations of the Paris Basin (France). Sedimentary Geology 197: 267-289.

Wagner GA, Coyle DA, Duyster J, Henjes-Kunst F, Peterek A, Schröder B. et al. 1997. Post-Variscan thermal and tectonic evolution of the KTB site and its surroundings. J Geophys Res 102 (B8): 18221-18232.

Xu C, Mansy JL, Van den Haute P, Guillot F, Zhou Z, Chen J, et al. 2009. Late- and post-Variscan evolution of the Ardenne in France and Belgium: constraints from apatite fission-track data. In: Lisker F, Ventura B, Glasmacher UA, eds. Thermochronological Methods: From Palaeotemperature Constraints to Landscape Evolution Models. Geological Society, London, Special Publications 324: 167-179.

Yans J. 2003a. An overview of the saprolites of Belgium and their potential kaolinitic supplies to Mesozoic and Cenozoic sediments. Géologie de la France 2003(1): 33-37.

Yans J. 2003b. Chronologie des sédiments kaoliniques faciès wealdiens (Barrémien moyen Albien supérieur, Bassin de Mons) et de la saprolite polyphasée (Crétacé inférieur et Miocène inférieur) de la Haute-Lesse (Belgique). Implications géodynamiques et paléoclimatiques. Thèse de $3^{\mathrm{e}}$ cycle, Faculté Polytechnique de Mons and Université de Paris-Sud Orsay, 316 p.

Ziegler PA. 1987. Late Cretaceous and Cenozoic intra-plate compressional deformations in the Alpine foreland - a geodynamic model. Tectonophysics 137: 389-420.

Ziegler PA. 1990. Geological Atlas of Western and Central Europe. 2nd. Ed. Shell International Petroleum Mij. B.V. Bath: Geological Society, London, Publishing House, 239 p.

Cite this article as: Barbarand J, Bour I, Pagel M, Quesnel F, Delcambre B, Dupuis C, Yans J. 2018. Post-Paleozoic evolution of the northern Ardenne Massif constrained by apatite fission-track thermochronology and geological data, BSGF - Earth Sciences Bulletin 189 : 16. 